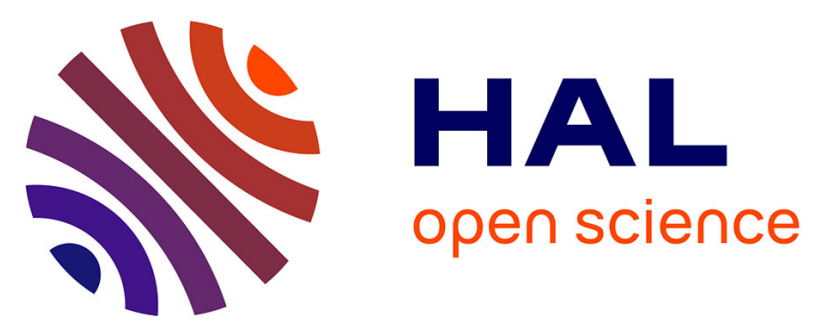

\title{
Planar Chiral Phosphoramidites with a Paracyclophane Scaffold: Synthesis, Gold(I) Complexes, and Enantioselective Cycloisomerization of Dienynes
}

Zhiyong Wu, Kevin Isaac, Pascal Retailleau, Jean-François Betzer, Arnaud Voituriez, Angela Marinetti

\section{To cite this version:}

Zhiyong Wu, Kevin Isaac, Pascal Retailleau, Jean-François Betzer, Arnaud Voituriez, et al.. Planar Chiral Phosphoramidites with a Paracyclophane Scaffold: Synthesis, Gold(I) Complexes, and Enantioselective Cycloisomerization of Dienynes. Chemistry - A European Journal, 2016, 22 (10), pp.3278-3281. 10.1002/chem.201504658 . hal-02152297

\section{HAL Id: hal-02152297 \\ https://hal.science/hal-02152297}

Submitted on 20 Sep 2019

HAL is a multi-disciplinary open access archive for the deposit and dissemination of scientific research documents, whether they are published or not. The documents may come from teaching and research institutions in France or abroad, or from public or private research centers.
L'archive ouverte pluridisciplinaire HAL, est destinée au dépôt et à la diffusion de documents scientifiques de niveau recherche, publiés ou non, émanant des établissements d'enseignement et de recherche français ou étrangers, des laboratoires publics ou privés. 


\title{
Planar Chiral Phosphoramidites with Paracyclophane Scaffold: Synthesis, Gold(I) Complexes and Enantioselective Cycloisomerization of Dienynes
}

\author{
Zhiyong Wu, Kévin Isaac, Pascal Retailleau, Jean-François Betzer, ${ }^{*}$ Arnaud Voituriez* and Angela \\ Marinetti[a]
}

\begin{abstract}
The key structural feature of the new phosphoramidites is a paracyclophane scaffold in which two aryl rings are tethered by both a 1,8-biphenylene unit and a O-P-O bridge. Suitable aryl substituents generate planar chirality. The corresponding gold(I) complexes promote the cycloisomerization of prochiral nitrogentethered dienynes. These reactions afford bicyclo[4.1.0]heptene derivatives displaying three contiguous stereogenic centres, with very high diastereoselectivity and up to $95 \%$ ee.
\end{abstract}

The gold(I)-catalyzed cycloisomerizations of unsaturated substrates (alkenes, alkynes, allenes), represent powerful tools for the synthesis of a wide range of carbocyclic, heterocyclic and polycyclic molecules. Recent studies in this field have led to the discovery of highly effective catalytic systems, to a better understanding of reaction mechanisms, as well as to applications to the synthesis of natural products and bioactive compounds. ${ }^{[1]}$ Moreover, the development of asymmetric variants has increased significantly the utility and scope of these reactions. ${ }^{[2]}$ Among others, phosphorus ligands have been designed for building chiral catalysts, by following three main strategies: the use of bimetallic gold complexes of atropisomeric diphosphines, ${ }^{[3]}$ the use of chiral counterions (mainly chiral phosphoric acid derivatives $)^{[4]}$ and the use of phosphoramidite ligands with bulky and extended substituents surrounding the metallic centre. ${ }^{[5]}$ In addition to these well-established strategies, our group has recently developed a new approach based on the use of phosphahelicenes as chiral ligands. ${ }^{[6]}$ Generally speaking, the specific linear coordination of gold $(\mathrm{I})$ complexes positions the chiral ligand to the reactive site opposite with respect to the gold center, rendering the design of efficient chiral ligands highly challenging.

A quick overview of the phosphoramidite-type ligands ${ }^{[7]}$ commonly applied to gold catalysis shows that they display either central or axial chirality, as typified in Scheme 1(a), while, to the best of our knowledge, planar-chiral phosphoramidites haven't been used so far. ${ }^{[3 a, 8]}$ Thus, in order to complement and expand the potential of gold-catalyzed enantioselective reactions, we have designed new phosphoramidite ligands with planar chirality of the general formula IV, in which the phosphorus

[a] Z. Wu, K. Isaac, Dr. P. Retailleau, Dr. J.F. Betzer, Dr. A. Voituriez, Dr. A. Marinetti

Institut de Chimie des Substances Naturelles, ICSN - CNRS UPR 2301, Université Paris-Sud, Université Paris-Saclay,

1, av. de la Terrasse, 91198 Gif-sur-Yvette, France.

E-mail: arnaud.voituriez@cnrs.fr and jean-françois.betzer@cnrs.fr function is included into a disubstituted paracyclophane scaffold The targeted paracyclophanes display a 1,1'-biphenylene unit and a O-P-O chain tethering the arylidene groups. ${ }^{[9]}$ Planar chirality is generated by adding aryl substituents ( $\mathrm{Ar}$ ) on both sides of the paracyclophane moiety.

Based on our previous work on phosphoric acids with paracyclophane structures, ${ }^{[9]}$ we anticipated that these phosphoramidites will display peculiar geometries, giving a singular orientation of the aryl substituents around the metal center (see hereafter, Figure 1). In this respect our new ligands will hopefully complement the known ones, as far as the spatial arrangement of the aryl substituents in complexes such as I or III (Scheme 1), is known to induce fine tuning of the stereochemical control in catalytic reactions.

As an initial study, we report here on the synthesis of the representative phosphoramidites 1 (Scheme 2) and preliminary investigations on the catalytic behaviour of their gold complexes.

(a)

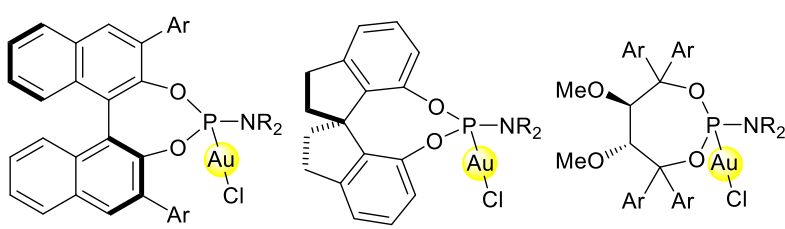

(I)

(II)

(III)

(b)

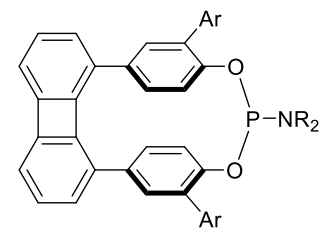

(IV)

(this work)

Scheme 1. (a) BINOL, ${ }^{[5 a, b, 5 d, 5 f, g]}$ SPINOL ${ }^{[5 d, 5 f]}$ and TADDOL ${ }^{[5 c, 5 e, 5 h]}$ derived chiral phosphoramidites commonly used in gold catalysis; (b) targeted phosphoramidites.

The targeted phosphoramidites $\mathbf{1}$ display a paracyclophane ring in which a 1,8-biphenylene unit tethers the arylidene groups. The same biphenylene tether had been used in our previous work to synthesize chiral paracyclophane-based phosphoric acids. ${ }^{[0]}$ The synthesis of the desired phosphoramidites $\mathbf{1}$ has been carried out by reacting the $m$-terphenyl-substituted diphenol 2 with $((S)-\mathrm{Ph}(\mathrm{Me}) \mathrm{CH})_{2} \mathrm{NPCl}_{2}$, after deprotonation with $\mathrm{NaH}$ (Scheme 2). This macrocyclization reaction occurs in high yield $(85 \%)$, since the phenol units in the substrate are constrained in a parallel arrangement, perfectly suitable for cyclization. 


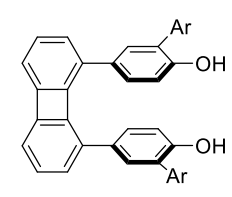

2, $\mathrm{Ar}=m$-terphenyl

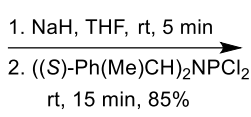

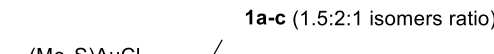

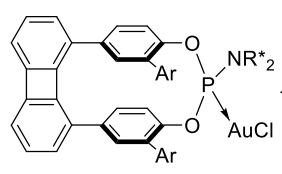

(S)-3a

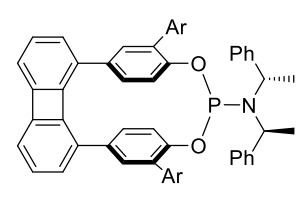

1a-c $(1.5: 2: 1$ isomers ratio $)$ $\left(\mathrm{Me}_{2} \mathrm{~S}\right) \mathrm{AuCl}$,
$\mathrm{CH}_{2} \mathrm{Cl}_{2}, \mathrm{rt}, 30 \mathrm{~min}$

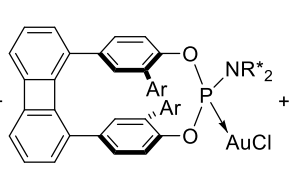

$\left(R_{P}, S\right)-\mathbf{3 b}$

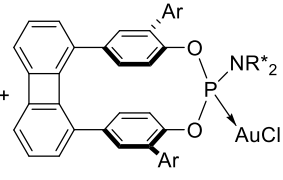

$\left(S_{P}, S\right)-3 \mathbf{c}$
Scheme 2. Synthesis of the diastereomeric phosphoramidites 1 and the corresponding gold complexes 3 .

The reaction affords a mixture of the three expected diastereomers that haven't been separated at this step. Instead, the mixture has been reacted with $\left(\mathrm{Me}_{2} \mathrm{~S}\right) \mathrm{AuCl}$ to afford the corresponding mixture of gold complexes 3a-c. Compound $\mathbf{3 a}$ was isolated in pure form by column chromatography $\left(\delta^{31} \mathrm{P}=\right.$ $116 \mathrm{ppm}$ in $\left.\mathrm{CH}_{2} \mathrm{Cl}_{2} ;[\alpha]_{D}=-105\left(\mathrm{c}=1, \mathrm{CHCl}_{3}\right)\right)$. It displays an achiral paracyclophane unit in which the two $m$-terphenyl substituents are located on the same side of the macrocyclic ring.

The epimeric compounds $\mathbf{3 b}$ and $\mathbf{3} \mathbf{c}$ were separated by fractional crystallization from a saturated ethyl acetate/ $n$-heptane solution. Compound $3 \mathbf{b}\left(\delta^{31} \mathrm{P}=114 \mathrm{ppm} ;[\alpha]_{D}=-132(\mathrm{c}=1\right.$, $\left.\left.\mathrm{CHCl}_{3}\right)\right)$ was obtained first, as a crystalline solid, and $3 \mathbf{c}\left(\delta^{31} \mathrm{P}=\right.$ $\left.111 \mathrm{ppm} ;[\alpha]_{D}=+78\left(\mathrm{c}=0.1, \mathrm{CHCl}_{3}\right)\right)$ was isolated then from the mother liquor. The structural features and stereochemistry of $\mathbf{3 b}$ could be unambiguously determined from the X-ray structure shown in Figure 1A. Compound $\mathbf{3 b}$ displays a chiral $\left(R_{p}\right)$ configured paracyclophane scaffold.

Figures $1 \mathrm{~B}$ and $1 \mathrm{C}$ are intended to compare the structural features of the gold complex $\left(\left(R_{p}\right)-3 \mathbf{b}\right)$ with those of the gold complex of a Monophos-type phosphoramidite la. ${ }^{[5 b]}$ Both phosphoramidites display the same bis[(S)-1-phenylethyl]amino group on phosphorus (pink color). For clarity and comparison purposes, the two phenyl groups of the terphenyl units of $\left(R_{p}\right)-\mathbf{3 b}$ have been deleted.

The schematic views of the two phosphoramidite complexes have been superimposed in Figure 1D, so that their O-P-O units and their gold centers are lined up. From this view, the divergent geometrical features of the two complexes and the different orientation of the aromatic substituents around the gold center appear unambiguously. The planar chiral phosphoramidite ligand in $\mathbf{3 b}$ lacks the C2-symmetry typically found in chiral phosphoramidites. As a consequence, two different Au- $\mathrm{C}_{i p s o}$ non-bonding distances can be measured, at 3.494 and $6.019 \AA$ respectively. The first one is significantly shorter and the second one significantly longer than the average $\mathrm{Au}-\mathrm{C}_{\text {ipso }}$ distance in the C2-symmetric complex la $(4.650 \AA)$.
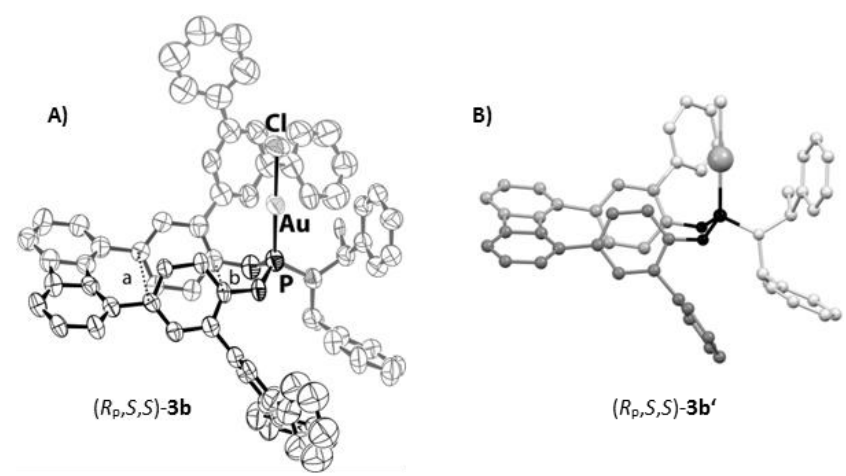

$\left(R_{\mathrm{p}}, S, S\right)-\mathbf{3} \mathbf{b}^{\prime}$

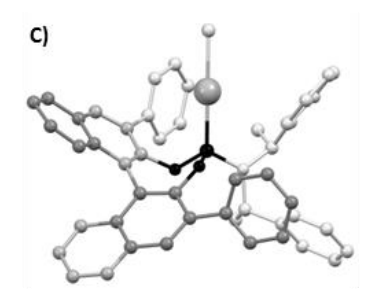

$\left(S_{a}, S, S\right)-$ la

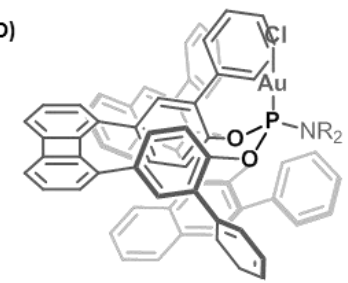

Figure 1. A) ORTEP drawing for the gold complex $\left(R_{\mathrm{p}}, S, S\right)-3 \mathbf{b}$. Selected bond length ( $\AA$ ): P-Au, 2.22; $\mathrm{Au}-\mathrm{Cl}, 2.27$; non-bonding distances: $a=3.83, b=3.43$, $\mathrm{Au}-\mathrm{C} 15=3.49$. Bond angle: $\mathrm{P}-\mathrm{Au}-\mathrm{Cl}, 178.3$ degrees. B) Simplified Mercury view of the gold complex $\left(R_{\mathrm{p}}, S, S\right)$-3b (two phenyl groups of each $m$-terphenyl unit have been deleted). C) Mercury view of the Monophos-type phosphoramidite gold complex $\left(S_{\mathrm{a}}, S, S\right)$-la $(\operatorname{CCDC} 767448)^{[5 b]}$. D) Overlying of the gold complexes la (light grey) and 3b' (dark grey).

The divergent structural features of these two complexes might generate divergent catalytic behaviors and applications. However, at first, the potential of the new complex $\left(R_{p}, S\right)-3 \mathbf{b}$ in terms of chiral induction must be established. This is the purpose of the preliminary catalytic studies reported hereafter.

The new gold complexes 3a-c have been used as catalysts for the cycloisomerization of $N$-tethered enynes into bicyclo[4.1.0]heptanes, by starting with the benchmark substrate $4^{[3 h, i, 5 e, 10]}$ (Table 1).

Activation of 3 with $\mathrm{AgBF}_{4}$ afforded good catalysts giving total conversion after $24 \mathrm{~h}$ at r.t., with enantiomeric excesses of $26 \%$, $77 \%$ and $64 \%$ for $\mathbf{3 a}, \mathbf{3 b}$ and $\mathbf{3} \mathbf{c}$ respectively (entries $1-3$ ).

Table 1. Screening of the chiral gold catalysts 3 in the cycloisomerization of the $N$-tethered 1,6-enyne 4 .

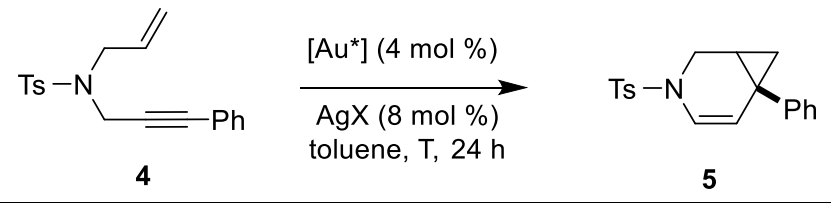

\begin{tabular}{llllll}
\hline Entry & {$\left[\mathrm{Au}^{*}\right]$} & $\mathrm{X}$ & $\mathrm{T}\left({ }^{\circ} \mathrm{C}\right)$ & Yield $(\%)^{[\mathrm{a}]}$ & e.e. $(\%)^{[\mathrm{b}]}$ \\
\hline 1 & 3a & $\mathrm{BF}_{4}$ & $\mathrm{rt}$ & 89 & $26(1 R)$ \\
2 & 3b & $\mathrm{BF}_{4}$ & $\mathrm{rt}$ & 91 & $77(1 S)$ \\
3 & 3c & $\mathrm{BF}_{4}$ & rt & 95 & $64(1 R)$ \\
4 & 3b & $\mathrm{BF}_{4}$ & 10 & 25 & $78(1 S)$
\end{tabular}




\begin{tabular}{llllll}
5 & 3b & OTf & rt & 72 & $55(1 S)$ \\
6 & 3b & $\mathrm{NTf}_{2}$ & rt & 65 & $66(1 S)$ \\
7 & 3b & $\mathrm{SbF}_{6}$ & rt & 95 & $74(1 S)$ \\
8 & 3b & $\mathrm{SbF}_{6}$ & 0 & 94 & $79(1 S)$ \\
\hline
\end{tabular}

[a] Isolated yield. [b] Determined by HPLC on a chiral stationary phase.

Complex $\mathbf{3} \mathbf{b}$ has been selected then for further experiments. The effect of the counterion has been investigated as shown in entries $4-7$ by combining $\mathbf{3 b}$ with various silver salts. These experiments have highlighted $\mathbf{3} \mathbf{b} / \mathrm{AgSbF}_{6}$ as the best catalyst which allows total conversion even at $0^{\circ} \mathrm{C}$. A good, $79 \%$ enantiomeric excess has been attained under these conditions (entry 8)..$^{[11]}$

After these encouraging experiments, we have considered a variant of this cycloisomerization reaction in which the prochiral dien-ynes 6a-i are used as the substrates (Table 2).

Table 2. Enantioselective cycloisomerization of $\mathrm{N}$-tethered 1,6dienynes.

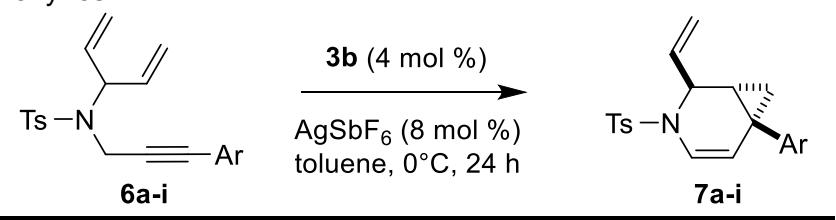

\begin{tabular}{lllll}
\hline Entry & $\mathrm{Ar}$ & Product & Yield (\%) ${ }^{[a]}$ & e.e. (\%) ${ }^{[\mathrm{b}]}$ \\
\hline 1 & $\mathrm{Ph}$ & $\mathbf{7 a}$ & 92 & 90 \\
2 & $3,4-\mathrm{Cl}-\mathrm{C}_{6} \mathrm{H}_{3}$ & $\mathbf{7 b}$ & 71 & 84 \\
3 & $4-\mathrm{NO}_{2}-\mathrm{C}_{6} \mathrm{H}_{4}$ & $7 \mathbf{c}$ & 33 & 67 \\
4 & $3,5-{\mathrm{Me}-\mathrm{C}_{6} \mathrm{H}_{3}}$ & $7 \mathbf{d}$ & 95 & 88 \\
5 & $2-\mathrm{MeO}-\mathrm{C}_{6} \mathrm{H}_{4}$ & $7 \mathbf{e}$ & 96 & 86 \\
6 & $3-\mathrm{MeO}-\mathrm{C}_{6} \mathrm{H}_{4}$ & $\mathbf{7 f}$ & 95 & 84 \\
7 & $4-\mathrm{MeO}-\mathrm{C}_{6} \mathrm{H}_{4}$ & $7 \mathbf{g}$ & 93 & 83 \\
8 & $2,4-\mathrm{MeO}-\mathrm{C}_{6} \mathrm{H}_{3}$ & $7 \mathbf{h}$ & 90 & 87 \\
9 & $2,6-\mathrm{MeO}-\mathrm{C}_{6} \mathrm{H}_{3}$ & $7 \mathbf{i}$ & 94 & 95 \\
\hline
\end{tabular}

[a] Isolated yield. [b] Determined by HPLC on a chiral stationary phase.

In this case, the chiral catalyst is expected to differentiate the enantiotopic vinyl groups of the substrate, i.e. to control the stereochemistry of both the cyclopropane ring and the additional stereogenic centre in the final product. Reactions of this class have been carried out so far by means of chiral platinum catalysts which gave good enantiomeric excesses $(80-95 \%$ ee, 4 examples), but only moderate catalytic activity (28-66\% yield). ${ }^{[10]}$

The gold complex $\mathbf{3} \mathbf{b}$, activated by $\mathrm{AgSbF}_{6}$, proved to be a very efficient catalyst in terms of both catalytic activity and stereoselectivity. The expected bicyclic compound $7 \mathrm{a}(\mathrm{Ar}=\mathrm{Ph})$ was obtained as a single diastereomer in $92 \%$ yield and $90 \%$ ee (entry 1). Enantiomeric excesses of $83-95 \%$ were obtained also for the dichloro-substituted substrate $\mathbf{6 b}$ (entry 2) and the electron-rich substrates $6 \mathbf{d}-\mathbf{i}$ (6 examples, entries 4-9). Notably, the 4-nitrophenyl substituted dienyne 7c, which is known to be inert under platinum catalysis, ${ }^{[10]}$ was converted into the desired bicyclo[4.1.0]heptane in $33 \%$ yield and $67 \%$ ee when using $3 b$ as the catalyst (entry 3 ).

Overall, the experiments above demonstrate the efficiency of the new planar-chiral phosphoramidite $\mathbf{3 b}$, both in terms of catalytic activity and enantioselectivity. They demonstrate that the paracyclophane scaffold based on a biphenylene unit is chemically and configurationally stable under the conditions of gold catalysis. From here, it will be possible to modulate extensively the substitution pattern of this paracyclophane scaffold, ${ }^{[9]}$ by changing both the aryl and the nitrogen substituents, in order expand and optimize their uses in a variety of gold catalysed processes.

In conclusion, we have synthesized and characterized new chiral phosphoramidites displaying an unprecedented paracyclophane structure. We have demonstrated, for the first time, the ability of planar-chiral gold(I) complexes to attain high levels of enantioselectivities in enyne cycloisomerisation reactions. Especially, starting from $\mathrm{N}$-tethered prochiral dienynes, the corresponding bicyclo[4.1.0]heptane derivatives with three contiguous stereocenters, were obtained in good yields, with excellent diastereoselectivity and up to $95 \%$ ee.

The new ligands reported here expand the well-established series of cyclic phosphoramidites as chiral auxiliaries in asymmetric catalysis. Further studies on their catalytic applications are ongoing.

\section{Experimental Section}

General procedure for $\mathrm{Au}(\mathrm{I})$-catalyzed cycloisomerizations of 1,6enynes:

To a solution of the gold(l) catalyst $(2.5 \mathrm{mg}, 0.002 \mathrm{mmol}, 4 \mathrm{~mol} \%)$ and the enyne or dienyne substrates 4 or $6(0.05 \mathrm{mmol}, 1$ equiv. $)$ in toluene $(1 \mathrm{~mL}), \mathrm{AgSbF}_{6}(1.4 \mathrm{mg}, 0.004 \mathrm{mmol}, 8 \mathrm{~mol} \%$ ) and another $0.5 \mathrm{ml}$ of toluene were added sequentially. The mixture was stirred at $0{ }^{\circ} \mathrm{C}$ for 20 72 hours. The reaction was monitored by ${ }^{1} \mathrm{H}$ NMR. Volatils were removed under reduced pressure and the final product was purified by column chromatography (heptane/ethyl acetate $=90 / 10$ to $80 / 20$ ). Enantiomeric excesses have been measured by chiral HPLC. Samples of racemic compounds have been obtained via (acetonitrile)[(2-biphenyl)di-tertbutylphosphine]gold(I) hexafluoroantimonate or $\mathrm{PtCl}_{2}$ promoted cycloisomerizations.

6-phenyl-3-tosyl-2-vinyl-3-azabicyclo[4.1.0]hept-4-ene ${ }^{[10]} \quad$ (7a) $\quad(92 \%$ yield, $95 / 5$ d.r. $)$. ${ }^{1} \mathrm{H}$ NMR $\left(500 \mathrm{MHz}, \mathrm{CDCl}_{3}\right) \delta 7.70(\mathrm{~d}, J=7.5 \mathrm{~Hz}, 2 \mathrm{H})$, $7.33(\mathrm{~d}, J=8.0 \mathrm{~Hz}, 2 \mathrm{H}), 7.27(\mathrm{~d}, J=7.0 \mathrm{~Hz}, 2 \mathrm{H}), 7.22-7.15(\mathrm{~m}, 3 \mathrm{H}), 6.30$ (d, $J=8.0 \mathrm{~Hz}, 1 \mathrm{H}$ ), 5.87 (ddd, $J=16.5,10.5,6.0 \mathrm{~Hz}, 1 \mathrm{H}), 5.59$ (d, $J=8.0$ $\mathrm{Hz}, 1 \mathrm{H}), 5.28(\mathrm{~d}, J=16.5 \mathrm{~Hz}, 1 \mathrm{H}), 5.15(\mathrm{~d}, J=11.0 \mathrm{~Hz}, 1 \mathrm{H}), 4.80(\mathrm{~d}, J=$ $6.0 \mathrm{~Hz}, 1 \mathrm{H}), 2.44(\mathrm{~s}, 3 \mathrm{H}), 1.77(\mathrm{dd}, J=8.0,7.0 \mathrm{~Hz}, 1 \mathrm{H}), 1.28(\mathrm{dd}, J=8.0$, $5.0 \mathrm{~Hz}, 1 \mathrm{H}$ ), 0.40 (dd, $J=7.0,5.0 \mathrm{~Hz}, 1 \mathrm{H}) ;{ }^{13} \mathrm{C} \mathrm{NMR}\left(75 \mathrm{MHz}, \mathrm{CDCl}_{3}\right)$ $143.8(\mathrm{C}), 143.6(\mathrm{C}), 136.5(\mathrm{C}), 136.2(\mathrm{CH}), 129.9(\mathrm{CH}), 128.6(\mathrm{CH})$, $127.4(\mathrm{CH}), 127.1(\mathrm{CH}), 126.5(\mathrm{CH}), 118.7(\mathrm{CH}), 117.9(\mathrm{CH}), 116.5\left(\mathrm{CH}_{2}\right)$, $52.9(\mathrm{CH}), 36.0(\mathrm{CH}), 22.6(\mathrm{C}), 21.7\left(\mathrm{CH}_{3}\right), 21.2\left(\mathrm{CH}_{2}\right)$; HPLC Analysis: $90 \%$ ee [CHIRALPAK® IC, $25^{\circ} \mathrm{C}, 1 \% \mathrm{EtOH} / n$-heptane, $1 \mathrm{~mL} / \mathrm{min}, 220$ $\mathrm{nm}$, retention times: $29.7 \mathrm{~min}$ (major) and $33.4 \mathrm{~min}$ (minor)]. 
6-(2,6-dimethoxyphenyl)-3-tosyl-2-vinyl-3-azabicyclo[4.1.0]hept-4ene (7i) (94\% yield, >95/5 d.r.). Melting point: $217-218{ }^{\circ} \mathrm{C} ;{ }^{1} \mathrm{H}$ NMR $(300$ $\left.\mathrm{MHz}, \mathrm{CDCl}_{3}\right) \delta 7.70(\mathrm{~d}, J=8.1 \mathrm{~Hz}, 2 \mathrm{H}), 7.30(\mathrm{~d}, J=8.1 \mathrm{~Hz}, 2 \mathrm{H}), 7.15(\mathrm{t}$, $J=8.4 \mathrm{~Hz}, 1 \mathrm{H}), 6.48(\mathrm{~d}, J=8.4 \mathrm{~Hz}, 2 \mathrm{H}), 6.19(\mathrm{~d}, J=8.1 \mathrm{~Hz}, 1 \mathrm{H}), 6.09$ (ddd, $J=17.0,10.2,7.2 \mathrm{~Hz}, 1 \mathrm{H}), 5.29(\mathrm{~d}, J=8.4 \mathrm{~Hz}, 1 \mathrm{H}), 5.28(\mathrm{~d}, J=$ $17.0 \mathrm{~Hz}, 1 \mathrm{H}), 5.12$ (d, $J=10.2 \mathrm{~Hz}, 1 \mathrm{H}), 4.79(\mathrm{~d}, J=7.2 \mathrm{~Hz}, 1 \mathrm{H}), 3.74$ (s, $6 \mathrm{H}), 2.43(\mathrm{~s}, 3 \mathrm{H}), 1.79(\mathrm{t}, J=7.8 \mathrm{~Hz}, 1 \mathrm{H}), 0.99(\mathrm{dd}, J=8.7,4.8 \mathrm{~Hz}, 1 \mathrm{H})$, $0.63(\mathrm{t}, J=5.7 \mathrm{~Hz}, 1 \mathrm{H}) ;{ }^{13} \mathrm{C} \mathrm{NMR}\left(75 \mathrm{MHz} \mathrm{CDCl}_{3}\right) 159.8(\mathrm{C}), 143.4(\mathrm{C})$, $137.6(\mathrm{CH}), 136.8(\mathrm{C}), 129.7(\mathrm{CH}), 128.4(\mathrm{CH}), 127.3(\mathrm{CH}), 119.24(\mathrm{C})$, $119.17(\mathrm{CH}), 117.6(\mathrm{CH}), 114.1\left(\mathrm{CH}_{2}\right), 103.9(\mathrm{CH}), 55.5\left(\mathrm{CH}_{3}\right), 54.7(\mathrm{CH})$ $35.1(\mathrm{CH}), 23.5\left(\mathrm{CH}_{2}\right), 21.7\left(\mathrm{CH}_{3}\right), 14.3(\mathrm{C})$; IR: $v_{\max }=2936,1639,1590$, 1471, 1351, 1249, 1166, 1109, 989, 912, 880, 873, 812, 783, 729, 708, $668 \mathrm{~cm}^{-1}$; HRMS (ESI) calcd. for $\mathrm{C}_{23} \mathrm{H}_{26} \mathrm{NO}_{4} \mathrm{~S}[\mathrm{M}+\mathrm{H}]^{+}: 412.1583$, found: 412.1610; HPLC Analysis: $95 \%$ ee [CHIRALPAK® IC, $25^{\circ} \mathrm{C}, 20 \% \mathrm{iPrOH} /$ $n$-heptane, $0.95 \mathrm{~mL} / \mathrm{min}, 224 \mathrm{~nm}$, retention times: $16.5 \mathrm{~min}$ (major) and $21.5 \mathrm{~min}$ (minor)].

\section{Acknowledgements}

This work was supported by the I.C.S.N. and the Agence Nationale de la Recherche (ANR Blanc SIMI7 2011, "Chiracid"). We acknowledge the CSC (Chinese Scholarship Council) for the $\mathrm{PhD}$ grant to Z.W. and the ANR for the PhD grant to K.I.

Keywords: planar chirality $\cdot$ phosphoramidite $\cdot$

cycloisomerisation $\cdot$ gold (I) catalysis $\bullet$ enantioselectivity

[1] a) E. Jiménez-Núñez, A. M. Echavarren, Chem. Rev. 2008, 108, 33263350; b) C. Obradors, A. M. Echavarren, Chem. Commun. 2014, 50, 16-28; c) C. Obradors, A. M. Echavarren, Acc. Chem. Res. 2014, 47, 902-912; d) A. Fürstner, Acc. Chem. Res. 2014, 47, 925-938; e) W. Yang, A. S. K. Hashmi, Chem. Soc. Rev. 2014, 43, 2941-2955.

[2] a) I. D. G. Watson, F. D. Toste, Chem. Sci. 2012, 3, 2899-2919; b) A. Marinetti, H. Jullien, A. Voituriez, Chem. Soc. Rev. 2012, 41, 48844908; c) F. López, J. L. Mascareñas, Beilstein J. Org. Chem. 2013, 9 , 2250-2264; d) Y.-M. Wang, A. D. Lackner, F. D. Toste, Acc. Chem. Res. 2014, 47, 889-901.

[3] a) M. P. Muñoz, J. Adrio, J. C. Carretero, A. M. Echavarren, Organometallics 2005, 24, 1293-1300; b) M. J. Johansson, D. J. Gorin, S. T. Staben, F. D. Toste, J. Am. Chem. Soc. 2005, 127, 18002-18003; c) Z. Zhang, R. A. Widenhoefer, Angew. Chem. Int. Ed. 2007, 46, 283285; d) R. L. LaLonde, B. D. Sherry, E. J. Kang, F. D. Toste, J. Am. Chem. Soc. 2007, 129, 2452-2453; e) M. A. Tarselli, A. R. Chianese, S. J. Lee, M. R. Gagné, Angew. Chem. Int. Ed. 2007, 46, 6670-6673; f) M. R. Luzung, P. Mauleón, F. D. Toste, J. Am. Chem. Soc. 2007, 129, 12402-12403; g) C.-M. Chao, M. R. Vitale, P. Y. Toullec, J.-P. Genêt, V. Michelet, Chem. Eur. J. 2009, 15, 1319-1323; h) C.-M. Chao, D. Beltrami, P. Y. Toullec, V. Michelet, Chem. Commun. 2009, 6988-6990; i) A. Pradal, C.-M. Chao, P. Y. Toullec, V. Michelet, Beilstein J. Org. Chem. 2011, 7, 1021-1029.

[4] a) G. L. Hamilton, E. J. Kang, M. Mba, F. D. Toste, Science 2007, 317, 496-499; b) K. Aikawa, M. Kojima, K. Mikami, Angew. Chem. Int. Ed 2009, 48, 6073-6077; c) R. L. LaLonde, Z. J. Wang, M. Mba, A. D. Lackner, F. D. Toste, Angew. Chem. Int. Ed. 2010, 49, 598-601.

[5] a) I. Alonso, B. Trillo, F. López, S. Montserrat, G. Ujaque, L. Castedo, A. Lledós, J. L. Mascareñas, J. Am. Chem. Soc. 2009, 131, 13020-13030 b) A. Z. González, F. D. Toste, Org. Lett. 2010, 12, 200-203; c) H. Teller, S. Flügge, R. Goddard, A. Fürstner, Angew. Chem. Int. Ed. 2010 , 49, 1949-1953; d) A. Z. González, D. Benitez, E. Tkatchouk, W. A. Goddard, F. D. Toste, J. Am. Chem. Soc. 2011, 133, 5500-5507; e) H. Teller, M. Corbet, L. Mantilli, G. Gopakumar, R. Goddard, W. Thiel, A. Fürstner, J. Am. Chem. Soc. 2012, 134, 15331-15342; f) S. SuárezPantiga, C. Hernández-Díaz, E. Rubio, J. M. González, Angew. Chem.
Int. Ed. 2012, 51, 11552-11555; g) D. Qian, H. Hu, F. Liu, B. Tang, W. Ye, Y. Wang, J. Zhang, Angew. Chem. Int. Ed. 2014, 53, 13751-13755; h) S. Klimczyk, A. Misale, X. Huang, N. Maulide, Angew. Chem. Int. Ed. 2015, 54, 10365-10369.

[6] a) K. Yavari, P. Aillard, Y. Zhang, F. Nuter, P. Retailleau, A. Voituriez, A. Marinetti, Angew. Chem. Int. Ed. 2014, 53, 861-865; b) P. Aillard, A. Voituriez, D. Dova, S. Cauteruccio, E. Licandro, A. Marinetti, Chem. Eur. J. 2014, 20, 12373-12376; c) P. Aillard, P. Retailleau, A. Voituriez, A Marinetti, Chem. Eur. J. 2015, 21, 11989-11993.

[7] J. F. Teichert, B. L. Feringa, Angew. Chem. Int. Ed. 2010, 49, 2486 2528.

[8] Concerning the use of planar-chiral ligand in gold catalysis, only planarchiral trivalent phosphines, mainly ferrocenylphosphine or ferrocenylphosphine amine ligands have been seldom used: a) Y. Ito, M. Sawamura, T. Hayashi, J. Am. Chem. Soc. 1986, 108, 6405-6406; b) S. D. Pastor, A. Togni, Tetrahedron Lett. 1990, 31, 839-840; c) A. Togni, S. D. Pastor, J. Org. Chem. 1990, 55, 1649-1664; d) X.-T. Zhou, Y.-R. Lin, L.-X. Dai, Tetrahedron Asym. 1999, 10, 855-862; e) X.-T. Zhou, Y.-R. Lin, L.-X. Dai, J. Sun, L.-J. Xia, M.-H. Tang, J. Org. Chem. 1999, 64, 1331-1334; f) A. S. K. Hashmi, M. Hamzić, F. Rominger, J. W. Bats, Chem. Eur. J. 2009, 15, 13318-13322; g) E. M. Barreiro, D. F. D. Broggini, L. A. Adrio, A. J. P. White, R. Schwenk, A. Togni, K. K. Hii, Organometallics 2012, 31, 3745-3754.

[9] The same biphenylene tether had been used in our previous work to synthesize configurationally stable chiral phosphoric acids: K. Isaac, J Stemper, V. Servajean, P. Retailleau, J. Pastor, G. Frison, K. Kaupmees, I. Leito, J.-F. Betzer, A. Marinetti, J. Org. Chem. 2014, 79, 9639-9646.

[10] H. Jullien, D. Brissy, R. Sylvain, P. Retailleau, J.-V. Naubron, S. Gladiali, A. Marinetti, Adv. Synth. Catal. 2011, 353, 1109-1124.

[11] We are aware of the silver effect in gold catalysis. The use of $4 \mathrm{~mol} \%$ [Ag] did not improve our results. For a review on the amount effect, see : a) M. Jia, M. Bandini, ACS Catal. 2015, 5, 1638-1652; b) B. Ranieri, I. Escofet, A. M. Echavarren, Org. Biomol. Chem. 2015, 13, 7103-7118. 


\section{Entry for the Table of Contents}

Layout 2:

\section{COMMUNICATION}
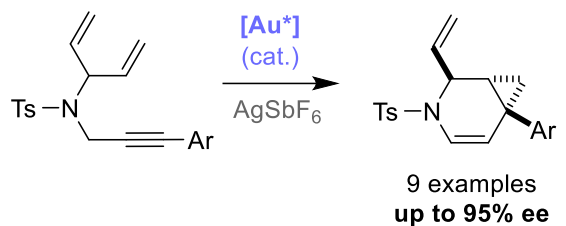

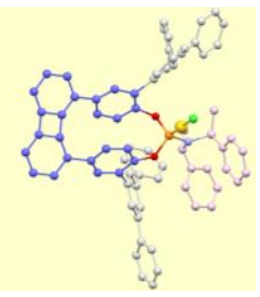

The key structural feature of the new phosphoramidites is a paracyclophane scaffold in which two aryl rings are tethered by both a 1,8-biphenylene unit and a OP-O bridge. Suitable aryl substituents generate planar chirality. Their gold(I) complexes promote the cycloisomerization of prochiral nitrogen-tethered dienynes to afford bicyclic derivatives with very high diastereoselectivity and up to $95 \%$ ee.
Zhiyong Wu, Kévin Isaac, Pascal Retailleau, Jean-François Betzer, * Arnaud Voituriez ${ }^{*}$ and Angela Marinetti

Page No. - Page No.

Planar Chiral Phosphoramidites with Paracyclophane Scaffold: Synthesis, Gold(I) Complexes and

Enantioselective Cycloisomerization of Dienynes 